\begin{tabular}{|l|l|l||}
\hline \multicolumn{2}{|c|}{ PublisherInfo } \\
\hline \hline PublisherName & $:$ & BioMed Central \\
\hline \hline PublisherLocation & $:$ & London \\
\hline \hline PublisherImprintName & $:$ & BioMed Central \\
\hline \hline
\end{tabular}

\title{
Systematic proteomics in yeast
}

\begin{tabular}{|l|l|l||}
\hline \multicolumn{2}{|c|}{ ArticleInfo } \\
\hline \hline ArticleID & $:$ & 4373 \\
\hline \hline ArticleDOI & $:$ & $10.1186 /$ gb-spotlight-20020110-01 \\
\hline \hline ArticleCitationID & $:$ & spotlight-20020110-01 \\
\hline \hline ArticleSequenceNumber & $:$ & 39 \\
\hline \hline ArticleCategory & $:$ & Research news \\
\hline \hline ArticleFirstPage & $:$ & 1 \\
\hline \hline ArticleLastPage & $:$ & 3 \\
\hline \hline & & RegistrationDate : 2002-01-10 \\
ArticleHistory & $:$ & OnlineDate \\
\hline \hline ArticleCopyright & $:$ & BioMed Central Ltd2002-01-10 \\
\hline \hline ArticleGrants & $:$ & \\
\hline \hline ArticleContext & $:$ & 130593311 \\
\hline \hline
\end{tabular}




\section{Jonathan B Weitzman}

Email: jonathanweitzman@hotmail.com

In the January 10 issue of Nature, two groups report large-scale proteomic projects designed to analyze protein complexes in the budding yeast Saccharomyces cerevisiae. Anne-Claude Gavin and researchers at the German company Cellzome used a tandem-affinity purification, 'TAP tagging', methodology to isolate protein complexes for subsequent mass spectrometry analysis (Nature 2002, 415:141-147). Analysis of 1,739 tagged genes lead them to the identification of 98 known nonredundant multiprotein complexes and 134 new complexes. They found partners for $78 \%$ of proteins and isolated complexes containing from 2 to 83 components (with an average of 12 per complex). Using a similar approach, Yuen Ho and researchers at the Canadian company MDS Proteomics began with 725 carefully chosen yeast bait proteins tagged with a Flag epitope (Nature 2002, 415:180-183). They identified 1,578 interacting proteins, representing $25 \%$ of the proteome. Both groups report novel features of protein complexes involved in the DNA damage response, kinase signaling pathways, cytoskeleton organization and so on. Ho et al. claim that their approach is more effective than previous studies based on two-hybrid screens. Gavin et al. have created a proteome map that defines relationships between protein complexes. Similar experiments with human orthologs provided evidence for an 'orthologous proteome' containing comparable protein complexes. These two studies highlight the feasibility of applying systematic purification and mass spectrometry technology to the analysis of protein interaction networks and present a proof-of-principle for future projects tackling mammalian proteomes.

\section{References}

1. Nature, [http://www.nature.com]

2. Cellzome, [http://www.cellzome.com]

3. A generic protein purification method for protein complex characterization and proteome exploration.

4. MDS Proteomics, [http://www.mdsp.com]

5. Systematic identification of protein complexes in Saccharomyces cerevisiae by mass spectrometry, [http://www.mdsp.com/yeast]

6. Towards an understanding of complex protein networks.

7. Yeast protein complex database, [http://yeast.cellzome.com/] 
(c) 2009-2013. SPi Global, Chennai, India. All rights reserved. 